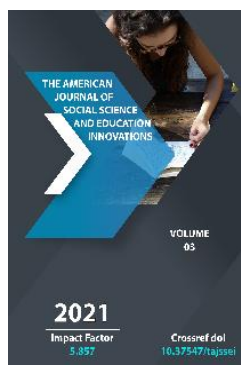

\title{
Jewellery Of Uzbekistan: Equipment And Technology
}

\section{Bobir Dadamukhamedov}

Head Of Sector Of The State Museum Of History Applied Arts And Crafts Of Uzbekistan, 2-Course, Researcher (PhD) National Institute Of Arts And Design Named After Kamoliddin Behzod, Uzbekistan

Copyright: Original content from this work may be used under the terms of the creative commons attributes 4.0 licence.

\section{ABSTRACT}

This article examines the origins of origin, the development of technology and technology, as well as various jewelry materials distributed among the local population as gold, silver, copper for the manufacture and design of jewelry of Uzbekistan in the period of the XIX-XX centuries.

\section{KEYWORDS}

Decoration, technique, coinage, embossing, stamping, gilding, process.

\section{INTRODUCTION}

One of the most developed forms of folk art of Uzbekistan at all times that folk masters have managed to preserve to this day is jewelry. Jewelers about art say this: "As long as there is at least one woman on earth, the business of jewelers will not die".
Jewelry is a peculiar field of folk art culture, it helps reveal the ideological and aesthetic ideals of people of past eras. The history of jewelry began long before they began to be made of precious metals. Then they began to make elegant jewelry from silver, gold and 
precious stones. In those days, according to traditional Uzbek jewelry, it was possible to read the main milestones of a woman's life. Jewelry told about wealth, the kind to which it belongs, about marital situation. Moreover, the younger the girl, the brighter and more elegant her jewelry "outfit" was.

\section{THE MAIN RESULTS AND FINDINGS}

Amulets and mascots, rings and pendants, necklace and bracelets of various forms and the sizes were also are allocated with ability to drive away evil spirits of which young women so were afraid. Jewelry tells about skill of handicraftsmen, about economic and working conditions, technology of processing of metals and stones, expresses style features of art of the era. In primitive society the aspiration to decoration of objects of the life, cult, arms, to decoration of itself appeared at the person. Especially valuable jewelry was produced mainly from gold, silver, with use of turquoise, rubies, pearls.

In Central Asia, both gold and silver, and from gemstones - turquoise and rubies so there were all conditions and prerequisites for production of jewelry was long since extracted. With production of jewelry of gold and silver there was a fashion of a pas any given jewelry, and the skill of jewelers gradually became a necessity.

Emergence of the numerous jewelry workshops obligatory for any feudal city of Central Asia, and at the end of XVIII - the beginning of the 19th century when there were Khiva, Bukhara and Kokand khanates is connected with it, their centers become fashion-makers. Jewelry is created, excellent in a form and receptions of figuration.
In XIX - the beginning of the XX centuries master jewelers worked in many cities: Bukhara, Khiva, Kokand, Samarkand, Shakhrisabz, Tashkent, Margilan, Andijan and many others. Bukhara, Tashkent, Khiva, Samarkand, Kokand were the largest centers of jewelry art of this time. There were specialized kishlaks of masters of jewelry: the kishlak (village) of "Zargarlik" near Jizzakh (Jizzakh region), Zargar near Denau (Surkhandarya region), Zargaron near Gizhduvan (Bukhara region). Bukhara, Kokand and Khiva were legislators of "fashion".

Jewelers dealt mainly with expensive metals gold, silver, from which they made tools, products and decorated them. The master put special jewelry pinches on the balance scales, weighed the necessary amount of metal, after which he put it in a refractory crucible and put it in a mountain, where he inflated the fire with special furs until the temperature necessary for melting was obtained. Then the crucible with molten metal was taken out with tongs forged from a whole piece of iron, drained the contents into a mold and, after some cooling, gave it the desired shape with the help of large and small hammers. The product is ready for ornamentation, but before decorating it, the surface of it was often polished using black river pebbles of suitable strength and convenient shape. Having prepared the form, the master jeweler selected the pattern, inscribed it using the appropriate technique of decoration.

Stamping - "cradles," which significantly cheaper products and created the opportunity for mass production - has become widespread in all cities of Uzbekistan, especially since the 2oth century. This was important, as by that time the demand for national jewelry from the 
Russian population, who had moved to Central Asia in large quantities, was increasing.

During stamping, a pre-prepared plate of the desired shape was applied to a metal stamp - a "bulb" and a pattern was knocked out using an impact tool, which was then adjusted by hand to give it clarity. With the help of a stamp, a pattern part was applied to the product, and sometimes the entire ornament with recesses "kuz-hon" for inserting stones.

The stamp was most often made of steel, and the ornament was applied with a special steel tool - "kalyam." In another, more complex way, they made products decorated with slotted ornaments - "shabaka." A pattern drawn by the master on paper was applied to the plate prepared of the right size, then using a "kalyam" and a hammer, the pattern was applied to the plate. After removing the paper with a small file, the background was removed and the desired ornament was created.

Unusually elegant and beautiful products made in the filigree technique - "nozik sim," for which silver wire made by the craftsmen themselves was used. To obtain the wire of the desired thickness, it was forged from a heated piece of silver and then pulled through a special plate with holes of various sizes. The resulting thin wire was decorated with serrations, which were applied using a "bulb" or weaving into a flagellum and flattening two wires, and now another method has begun to be used: moving the wire through a hole of a special plate, when rotating which sharp edges of the hole are applied to the wire minute serrations. In the manufacture of the product, segments of filigree thread soldered to each other, taking the necessary bend and creating the finest metal lace, from which earrings, bracelets were made, and in Tashkent there were nests for inserting stones. These cells, which were soldered with a special alloy on the surface of jewelry, were called "kuz-hona," or "girdak," which means a circle. Often filigree was decorated with tiny lined silver beads, the socalled grain ("zigirak"), which soldered to the products and very decorated them.

This was done as follows: small recesses were drilled in a piece of hurricane coal, into which pieces of silver were inserted, and this piece of coal was kept on fire until the metal melted. When it cooled and solidified, round silver beads were obtained. These round beads are currently produced without the use of hurricane coal. Small pieces of metal are cut from a plate or wire, which are melted on asbestos paper. The obtained cooled grains are laid and soldered into patterns in the form of pyramids, prisms, triangles, circles.

A simple and spectacular method of decoration is the application of black ("koraytirish"), which came into use under the influence of Caucasian masters. Black has the form of a powder, for the preparation of which a mixture of silver, copper, lead and combustible sulfur was cooked. After cooling, the mixture was pushed in a mortar, sieved through jelly, and washed in clean water to allow the sorbs to float and clean black to remain. The black thus prepared was mixed for viscosity with the brown and the recessed areas of the jewelry plate were filled. The plate was then heated on fire until the black was melted, and the black was to be flush with the metal surface. After cooling with a filer, the excess black was cleaned and ground with pulverized coal until the surface of the black became smooth and shiny.

Very close to the technique of applying black, the application of a vitreous alloy called 
enamel, which can be painted in various colors using metal oxides. Modern craftsmen do not make enamel paints themselves, but get them ready. Enamel is ground, passed through a sieve, washed and sprinkled with recessed parts of the jewelry, often fenced with gold or silver wire. During heating, the enamel melts and after filling the required space on the article is polished. Enamel was used before black, and then was supplanted by it as a cheaper method of decoration. A special composition, the so-called "white gold," was used.

This is an alloy of silver with gold, with the addition of copper, which significantly cheaper the product being made. Copper was also used as an independent material for making jewelry, and when they wanted to give the product of copper and other cheap metal the appearance of expensive, it was gilded. Gilding was applied by cold forging and using fire. Cold gilding, which was expressed in the fact that gold sheets were applied and inflated on the rough minted surface of the object, was of more ancient origin, but the most common is completely gilding with a special composition called amalgam, which was obtained in several ways. To produce it, gold was melted into small pieces, then mercury was poured, which "absorbed" gold. The resulting mixture was poured into "piyala" (cup) with cold water. After cooling, the mixture became like a jelly, and this mass was applied to the article, after which the object was kept above the fire. At the same time, mercury volatilized, and gold was firmly connected to the surface. Gilding in this way was very durable, but this is a difficult and long process, with the help of which only a few objects could be gilded in a day.

Another method of producing amalgam was that a thin sheet of gold was finely cut into “piyala” (cup), nitric and hydrochloric acid was poured there and put on fire. At the beginning, the contents of the "piyala" (cup) turned into liquid, then, with strong heating, the acids volatilized, and gold settled on the walls of the "piyala" (cup), into which water boiled with potash was poured. The water, mixing with gold, became cloudy yellow, a piece of zinc was thrown into it and an object was immersed for gilding. This late intake of gilding, called "tillakhal," is very close to the modern one, in which gold is dissolved in a mixture of nitric and hydrochloric acid, then evaporated to obtain a dark yellow mass of chloric gold, the aqueous solution of which is treated with ammonia and a precipitate of hot gold is obtained, which is filtered and dissolved in a solution of potassium cyanide.

\section{CONCLUSION}

Gold plate and gilding article are lowered vertically into obtained solution poured into vessel. When the current is applied between the electrolyte lowered into it by the gold plate and the product, a reaction occurs, as a result of which the smallest gold particles cover the product with an even layer of gilding.

Jewelers not only took into account the degree of accessibility of products to the buyer, but also monitored the variability of fashion. The task of cheapening and updating jewelry is also relevant today, the difference is only that fashion becomes common, as the line between the fashions of individual areas is erased.

The original works of jewelers in Uzbekistan testify to the fact that successes in this type of art and bright creative achievements are the result of an organic synthesis of national traditions and modernity. 


\section{REFERENCES}

1. Abdullaev T., D. Fakhretdinova, Khakimov A. Song in metal. - T., 1986. $-251 \mathrm{p}$.

2. Azizova N. Jewelry of Uzbekistan. - T., 1968. - 56 p.

3. D.A. Fakhretdinova Decorative and applied art of Uzbekistan. - T., 1972. $164 \mathrm{p}$.

4. D.A. Fakhretdinova Jewelry of Uzbekistan. - T., 1988. - 204 p.

5. Sycheva N. Jewelry of the peoples of Central Asia and Kazakhstan. - M, 1984. $-179 \mathrm{p}$.

6. Абдурашидовна, қ. А. (2020). ДЭВИД ФОНДИ ВА КОЛЛЕКЦИЯЛАРИДАГИ ЎЗБЕКИСТОННИНГ Х АСРИГА ОИД АШЁЛАР ВА УЛАРНИНГ ЎЗИГА ХОС ХУСУСИЯТЛАРИ. Маданият чоррахалари, 4(2).

7. Курбанова, А. А. (2015). К ВОПРОСУ О ПРЕДМЕТАХ, ОСВЕЩАЮЩИХ ДРЕВНЮЮ ИСТОРИЮУЗБЕКИСТАНА, ХРАНЯЩИХСЯ НЫНЕ В МУЗЕЕ АНТРОПОЛОГИИ И ЭТНОГРАФИИ ИМ. ПЕТРА ВЕЛИКОГО (КУНСТКАМЕРА) РОССИЙСКОЙ ФЕДЕРАЦИИ. Фундаментальные и прикладные исследования в современном мире, (10-5), 42-46.

8. Курбанова, Д. А. (2015). Об истории прикладного искусства Узбекистана XIX столетия и о предметах Государственного музея искусства народов Востока Российской Федерации. Молодой ученый, (10), 1513-1515.

9. Utanova, U. A. (2019). ScientificallyPhilosophical Analysis Of Cultural And Spiritual Heritage. International
Journal on Integrated Education, 2(1), 53-55.

10. Utanova, U. A. (2020). FOLK CULTURE IS A SOCIO-HISTORICAL PHENOMENON. International Engineering Journal For Research \& Development, 5(9), 5-5.

11. Рашидов Жамшид Хусан Угли (2020). СОВРЕМЕННЫЕ ПРОБЛЕМЫ И ТЕНДЕНЦИИ РАЗВИТИЯ КНИЖНОГО ДИЗАЙНА. Вестник науки и образования, (24-1 (102)), 106-109.

12. Рашидов, Ж. Х. У. (2020). СПОСОБЫ ИНТЕРПРЕТАЦИИ

ХУДОЖЕСТВЕННОЙ ЛИТЕРАТУРЫ В КНИЖНОЙ ГРАФИКЕ. ПРОбЛЕМЫ современной науки и образования, (2 (147)).

13. Атаханова, Ф. 3. (2019). Этно-стиль: на подиумах и реальности (на примере деятельности дизайнеров Узбекистана). European Journal of Arts, (3).

14. Ozodbek, N., Tolipov, F., \& Yunusova, X. (2019). Historical and ethnographic features of the Uzbek Kurash. International Journal of Recent Technology and Engineering, 8(2 Special Issue 3), 1614-1616.

15. Nematov, O. (2018). Historical and religious monument of muhammad sharif (Mevlanagrekushoh). Asian Journal of Multidimensional Research (AJMR), 7(9), 448-452.

16. Sayfullaev, N. Current Issues on Fine ARTS Education: Continuity and Prospects for Development. Religación, 4, 192-194.

17. Doniyorov, A., Kariev, A., Aminov, H., \& Karimov, N. (2021). The Level of Study of the Religious Image of Mavarounnahr in the IX-XII Centuries. 
The American Journal of Social Science and Education Innovations (ISSN - 2689-100x)

Published: March 25, 2021 | Pages: 212-217

Doi: https://doi.org/10.37547/tajssei/Volume03Issue03-29

Journal of Contemporary Issues in

Business and Government, 27(1), 413-

423.

18. Odilov, B. A., \& Karimov, N. R. (2020).

ANALYSIS OF TARGETED RESEARCH IN

20-30 YEARS OF THE XX CENTURY.

PalArch's Journal of Archaeology of

Egypt/Egyptology, 17(6), 8887-8893. 